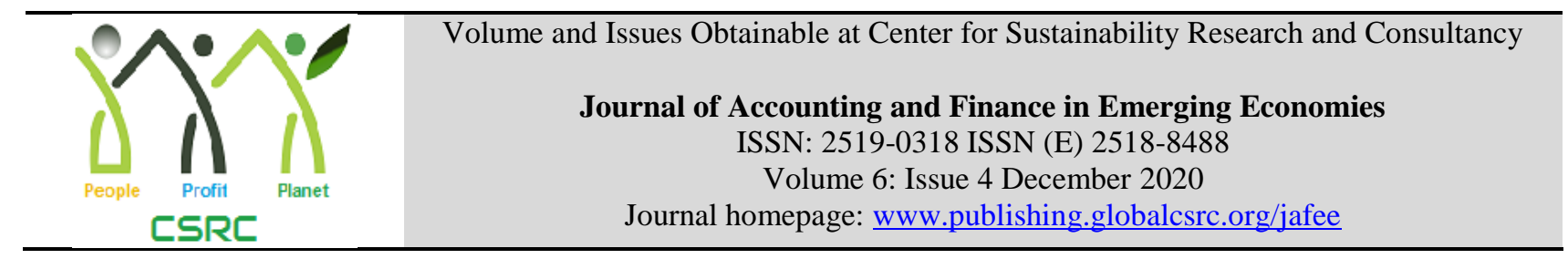

\title{
The Determinants of Price Change: Evidence from a Survey of Firms
}

\begin{tabular}{|c|c|}
\hline \multicolumn{2}{|c|}{$\begin{array}{l}\text { 1Nadeem Iqbal, }{ }^{\mathbf{2}} \text { Amjad Amin, }{ }^{\mathbf{3}} \text { Danish Wadood Alam } \\
{ }^{1 \& 2} \text { Assistant Professor at the Department of Economics University of Peshawar, Pakistan, } \\
\text { nadeemiqbal@ @op.edu.pk, amjadamin@uop.edu.pk } \\
{ }^{3} \text { Lecturer at the Department of Economics University of Peshawar, Pakistan, } \\
\text { danish_alam@ uop.edu.pk }\end{array}$} \\
\hline ARTICLE DETAILS & ABSTRACT \\
\hline $\begin{array}{l}\text { History } \\
\text { Revised format: November } \\
2020 \\
\text { Available Online: December } \\
2020\end{array}$ & $\begin{array}{l}\text { Price stability are important for macroeconomic stability, especially } \\
\text { for the economies, which are facing macroeconomic instability. } \\
\text { Contractionary monetary policy can play an important role in } \\
\text { minimizing the frequency of price change, so for effective monetary } \\
\text { policy, it is necessary to identify the determinants of price setting }\end{array}$ \\
\hline $\begin{array}{l}\text { Keywords } \\
\text { Price change, Price setting, } \\
\text { demand shocks, supply } \\
\text { shocks, Firm characteristic. }\end{array}$ & $\begin{array}{l}\text { behaviour. The objective of the study is to determine the patterns of } \\
\text { price setting of firms and responses of firms to economic shocks, i.e. } \\
\text { changes in demand and supply side factors, the role of firm } \\
\text { characteristics, institutional and other factors in determining the }\end{array}$ \\
\hline $\begin{array}{l}\text { JEL Classification: } \\
M O, M I\end{array}$ & $\begin{array}{l}\text { Industrial estates of Khyber Pakhtunkhwa. Price setting behavior is } \\
\text { measured through importance of demand and cost shocks for price } \\
\text { change. To estimate the effects of determinants of price change, } \\
\text { models are estimated through logistic technique. Firms' likelihood } \\
\text { of price increases higher than that to price decrease in response to } \\
\text { both demand and supply shocks. Furthermore, supply-side factors } \\
\text { lead to higher frequency of price change than demand-side factors } \\
\text { do. The cost of raw material and cost of energy are the most } \\
\text { important causes of price change, both for the price increase and } \\
\text { decrease. Demand and cost shocks are important determinants of } \\
\text { price change for imperfectly competitive firms, backward-looking } \\
\text { firms, firms run by managers having more information about } \\
\text { economic conditions, while credibility of central bank is important } \\
\text { determinant of price change in case of demand shocks only. Size of } \\
\text { firms and information set regarding expected inflation do not have } \\
\text { any effect. For effective monetary policy of Pakistan, credibility of } \\
\text { central bank has to be established to stabilize prices and pre-emptive } \\
\text { measures should be taken on the part of central bank to counter } \\
\text { supply shocks. }\end{array}$ \\
\hline
\end{tabular}

(C) 2020 The authors, under a Creative Commons AttributionNonCommercial 4.0

Corresponding author's email address: nadeemiqbal@uop.edu.pk

Recommended citation: Iqbal, N., Amin, A. \& Alam, D. W. (2020). The Determinants of Price Change: Evidence from a Survey of Firms. Journal of Accounting and Finance in Emerging Economies, 6(4), 1059-1068 


\section{Introduction}

For appropriate economic policy, especially for monetary policy, there is a need for deeper understanding of the characteristics and factors which affect the dynamics of prices. Nominal rigidities play a vital role in the transmission of shocks. Price rigidities affect the shocks intensities. The state of flexibility of price is important for the countries that intervene in the foreign exchange market. Price setting become important for the transmission of shocks when nominal exchange rate is not allowed to adjust. Moreover, it is the money wage rigidity, which ensures the real effect of monetary policy. Despite the significance of price rigidities, there is still no consensus on the theoretical mechanism of underlying facts of these rigidities and empirical analysis of the degree of these nominal rigidities.

What are the causes of variations in the price setting frequency at the firm level? How firms change their prices? Why some of the firms change their prices more often than the other firms? Literature has shown some of the factors which can trigger price. These factors are common such as level of competition, long-term contract with employees and other raw material suppliers, size of the firm and many other different actions, which are also known as pricing triggers (Blaudow and Burg, 2018; and Nakamura, Emi and Jon Steinsson, 2008). The demand and supply shocks may be small or large; the effect may be instantaneous or slow; it may vary from country to country and depends on the situation. These variations should be incorporated, for effective monetary policy, e.g. if the price rigidity is because of menu cost then the price setting mechanism should be designed in such a way that price change becomes less costly (Ball and Mankiw, 1994). Blinder (1991) is the pioneer study, who collected data through survey and tested macroeconomic theories of price rigidities, which covered the weakness in the studies done at the aggregate level, because aggregate data fail to give proper justification of price stickiness. This study opens another direction for research to study the nominal rigidities at the firm level using micro data collected through the survey (Taylor, 1999; and Hall and Yates, 1998) and find the same result as Blinder (1991), but with some additional facts.

In the case of Pakistan, Sohail and Fatima, (2018); Chaudary et al., (2011; 2016) and Malik et al., (2008) have stduied the price-setting behaviour of firms using survey based data but these studies have only focused on the pricing rule, frequency to adjust prices, magnitude of price change, and different types of information about price setting and have ignored the response of firms to change in prices to different shocks and the role of the firm characteristics in price setting. Why is the issue of price setting behaviour important? Why study how price are determined? Why study that the firm does not respond at a regular frequency to different demand and supply shocks? Answering these questions through understanding the price setting behaviour is significant for planning and implementation of monetary policy. The objective of the study is to analyze the determinants of price change of firms located in Industrial estates of Khyber Pakhtunkhwa, using survey based data and responses of firms to economic shocks, i.e. changes in demand and supply side factors, the role of firm characteristics, institutional and other factors in determining the channel of adjustment after these shocks and futher more to examine that upward response of price is more significant than downward response or not. Rest of the study is organized as: in section 2 theoretical background discussed, section 3 explain the econometric methodology and construction of variables, section 4 discuss data collection procedure, section 5 constists of results and analysis and section 6 is about conclusion and recommendation.

\section{Theoretical Framework}

Taylor (1999) developed staggered price contract model, which has the following features: this model explains some critical properties of price setting in the real world. Equations are the same both for price setting. First, consider the case of price setting. This model assumes that price is set for fixed, i.e. $\mathrm{N}$ periods, which is greater than $1(\mathrm{~N}>1)$. In this contract period, the firm does not change the price. In each period $1 / \mathrm{N}$ of the total firms change their prices. In any period, the price will be the average of prices set in $\mathrm{N}$ periods; in the current period and the last $\mathrm{N}-1$ period. In setting price, the firm 
incorporates all past and future information of price decisions of other firms. It means the price setting behaviour is both backward-looking and forward look.

For simplicity let's consider that price is set for two periods, i.e. $\mathrm{N}=2$, where " $\mathrm{P}_{\mathrm{t}}$ " is the price in a time " $t$ ", and " $\mathrm{Z}_{\mathrm{t}}$ " is the contract price depend on the price in a time " $\mathrm{t}$ ", "t-1" and real aggregate output $\left(\mathrm{Y}_{\mathrm{t}}\right)$.

So, the price setting equations of the model are:

$\log \left(\mathrm{P}_{\mathrm{t}}\right)=0.5\left\{\log \left(\mathrm{Z}_{\mathrm{t}}\right)+\log \left(\mathrm{Z}_{\mathrm{t}-1}\right)\right\}$

$\log \left(\mathrm{Z}_{\mathrm{t}}\right)=0.5\left\{\log \left(\mathrm{P}_{\mathrm{t}}\right)+\mathrm{E}_{\mathrm{t}}\left(\log \left(\mathrm{P}_{\mathrm{t}+1}\right)\right)\right\}+\gamma \log \left(\mathrm{Y}_{\mathrm{t}}\right)+\gamma \mathrm{E}_{\mathrm{t}}\left\{\log \left(\mathrm{Y}_{\mathrm{t}+1}\right)\right\}+\varepsilon_{\mathrm{t}}$

According to equation (1) current price is the average of the contract prices in time " $t$ " and " $t-1$ " and according to equation (2), contract prices in the two periods depend on prices and aggregate demand prevailing in the contract periods.

The model assumes a simple closed economy, so the money demand function is given as:

$$
\log \left(M_{t}\right)-\log \left(P_{t}\right)=\log \left(Y_{t}\right)
$$

$M_{t}$ : Money supply and the following stochastic rule determines it

$\log \left(M_{t}\right)=\log \left(M_{t-1}\right)+\gamma_{t}$

Where

$$
\operatorname{Cov}\left(\epsilon_{t}, \gamma_{t}\right)=0
$$

By substituting equation (4) in equation (2) i.e. contract prices and then put equation (1) that current price equation, i.e. $\mathrm{P}_{\mathrm{t}}$ in equation, the model derived the autoregressive equation for " $\mathrm{Y}_{\mathrm{t}}$ ", where the autoregressive coefficient of $\mathrm{Y}_{\mathrm{t}-1}$ is $c=d-\left(d^{2}-1\right)^{-1}$, where $d=(1+\gamma)(1-\gamma)^{-1}$, the moving average term depends on the price setting equations and shocks to money demand, i.e. $\gamma_{t}$, the parameter $\mathrm{c}$ will be large for small shocks of money demand " $\gamma_{t}$ ", and it will be persistence, it means $\gamma_{t}$ is the key parameter for the price setting. By putting equation (1) into equation (2), model proved that $Y_{t}$ show autoregressive behavior because price set by one firm i.e. $Z_{t}$ depend on price set by others firm i.e. $Z_{t-1}$, because of this autoregressive behavior, a shock to the money supply " $\gamma_{t}$ " has a significant effect on output and price level, because $d=(1+\gamma)(1-\gamma)^{-1}$, this autoregressive term $\left\{c=d-\left(d^{2}-1\right)^{-1}\right\}$ is contract multiplier, because it is similar to dynamic multiplier and because the effect on output because of money shock is for a long time. So, this model explains the dynamic relationship between price level, output and money supply. As the behaviour of price setting behaviour is heterogeneous across firms and concerning time. So, in the above model, other factors can be included, to give a more general form of price setting model.

\section{Econometric Model}

The empirical model for price setting behaviour given in equation (1) is constructed on the baisis of previous literature, objective of the study and theoretical framework discussed.

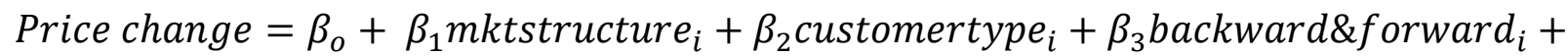
$\beta_{4}$ priceAdjutmentprocess $_{i}+\beta_{5}$ Credibility $_{i}+\beta_{6}$ Economicliteracy $_{i}++\beta_{7}$ informationset $_{i}+$ $\beta_{8}$ firmsize $_{i}+\mu_{i}$

Equation (1) consists of the determinants of price setting. The model is estimated through binary probit/logistic technique; the selection of technique depend on the nature of dependent variable and diagnostic tests. The construction of dependent and independent variables is discussed below.

Price setting is the dependent variable in equation (1), which is measured through price change. The price change is proxied through the importance of demand and cost shocks factors in case of the price increase/decrease, it does not explain the behaviour of price rigidity or flexibility, it indicates the significance of demand and cost factors that might cause to raise or lower the price of main products, whenever price change is required. It only explains the determinant of price change. For the demand shocks the variables taken are inflation, change in the price of the competitors, seasonal factors, changes 
in the tax rate, changes in the demand of your product, change in the level of competition and change in the exchange rate. For the cost shocks the variables taken are inflation, change in labour cost, change in financial cost, change in the cost of raw materials, change in the cost of energy, seasonal factors, government regulations and change in the exchange rate. The firms were asked to indicate the significance of the above factors that might cause to raise/lower the price of firm's product. After the collection of data, average of all the factors mentioned above of the cost shocks and demand shocks are taken. In this way four series of price change are constructed, which are proxied through the significance of demand and cost factors to change price. Each proxy of price change is regressed on a set of explanatory variables. Now, these series are in continuous form because of taking the average, but the value of variables in all cases is from 1 to 4 . The study can apply ordinary least square because the dependent variable is continuous form, but it will not achieve the objective of the study. So, the four series are converted into four dummies, i.e. categorical form, by rounding the values to nearest number in given ranking, i.e. 1 to 4 . Total four variables are taken to measure price setting behaviour, price change in case of demand and cost shocks in case of price increase and decrease, which are in categorical form.

Market structure is measure through degree of monopoly power to set price, the manager of the firms are asked that how they calculate the price of their product? i.e. a mark-up is applied to the unit variable costs, price is set at the level prevailing in the market, the price of main competitors is used as a reference, price is set jointly with other competitive firms, or any other option and all options are ranked from 1 to 5 respectively. To capture the type of customers, the firms are asked about the type of customers, i.e. whether they are regular, or occasional or of both type. To construct variable, each category is assigned specific number from 1 to 3. To capture Backward-looking and forward-looking behaviour, the firms are that their price decisions are based on the past information, current information, forecast about future or combination of all. All categories are assigned numbers from 1 to 4 to construct categorical variable.

To measure Price Adjustment Process, the firms are asked that suppose their current price is X, after computation, they find that it should be increased (decreased). Then in this case, they do it in one shot, gradually or it depends on the situation. Furthermore, the response of the firm is explored with respect to the different percentage change in price, i.e. less than 5\%, from $6 \%$ to $10 \%$ and more than $10 \%$. In all cases categories are same and are assigned numbers from 1 to 3 . To measure the credibility of the central bank policies in Pakistan, the firms are asked that in making decisions (e.g. investment, price), do they use the forecasts (e.g. about output growth and inflation) released by the State Bank of Pakistan? If the answer is yes then it considers State Bank of Pakistan credible, while the other response- no means notcredible: it means firms do not consider the reports of State Bank of Pakistan significant or trust worth. To construct binary variable, categories are assigned number 0 and 1 , i.e. yes $=1$, no $=0$.

To capture the economic literacy of firm managers, the firms are asked about how learn about current economic conditions and economic policies? i.e. from reports of State Bank of Pakistan, Ministry of Finance reports newspapers, electronic media and through discussion with personal relations/social capital. All these responses are in binary form, i.e. yes $=1$ and no $=0$. To measure economic literacy, the values of all responses are added for each firm. So higher the value of a firm in this question, more will be the economic literacy. To determine the set of information used in forecasting the inflation, the firms were asked about different macroeconomic and policy variables, which can be used of for expectation. All these options are assigned values 1 or 0 , to measure the set of information for forecasting all these values are added. The firm size is measured by total number of workers.

\section{Sample}

For this, a survey is conducted in the fiscal year 2017 from four major industrial estates of Khyber Pakhtunkhwa, i.e. Hayatabad Industrial Estate, Nowshera Industrial Estate, Gadoon Industrial Estate and 
Hattar Industrial Estate. A sample of 342 firms is selected from the filtered population through random sampling, and data is collected through direct face to face interview from the managers of the firms. Blinder et al. (1998) methodology is followed to design questionnaire for the study. It consists of five sections: section A on general information of firms; section $\mathrm{B}$ on Price setting; section $\mathrm{C}$ on determinants of price change; and section D on awareness of Central bank working.

\section{Results}

\subsection{Causes of Price Change}

This section explains the significance of various factors that might cause the firm to raise or lower the price of the main product. To find the determinants of price change, the firms are asked to rank the following from unimportant to very important, i.e. "Unimportant $=1$ ", "less important $=2$ ", "important $=3$ " and "very important $=4$ ". In table 1 the values show average response of the importance of demand and cost shocks factors in case of the price increase/decrease, it indicates the significance of demand and cost factors that might cause to raise or lower the price of main products, whenever price change is required. If mean value is greater than 2 , then the shock is important cause of price change, otherwise no.

According to the table 1, the cost of raw material and cost of energy are the most important determinants of price change, both for the price increase and decrease. According to table 1 the mean value of all variables for price increase is greater than the mean value in case of price decrease, it means firms give more important to demand and supply shocks in case of price increases than the decrease in price. The mean values of all variables of demand and supply shocks are greater than two in case of price increase; it shows that for the firms all mentioned factors in the table 1 are important determinants for price increase. While in case of price decrease, the mean value of most variables is less than two, so it can be inferred for price decrease; factors given in the table 1 are not important determinants of price decrease. Furthermore, the table 1 shows that overall for both price increase and decrease the supply side factor is more important determinants than demand-side factors because the mean value of supply-side factors are greater than the mean value of demand-side factors. Overall all factors are significant at $1 \%$ significance level.

Table 1 Causes of Price Change

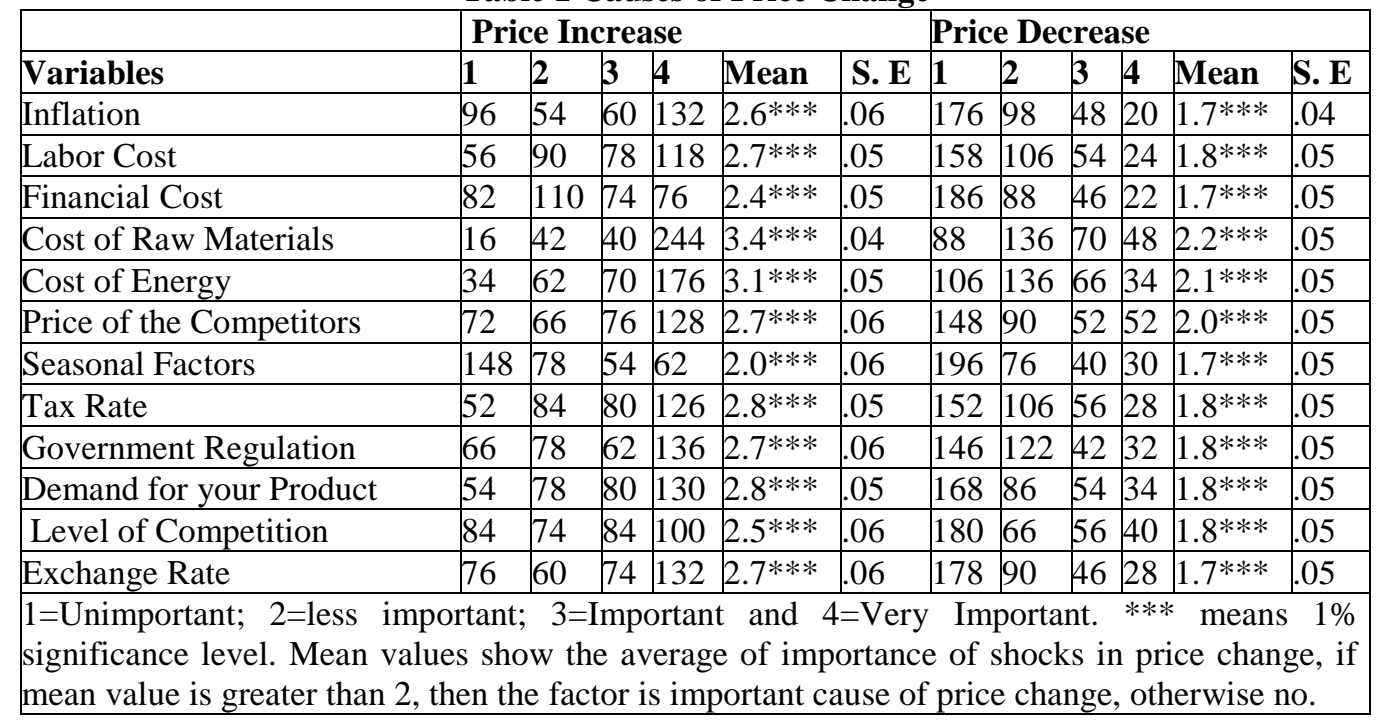

\subsection{Determinants of Price Change}

This section analyzed the determinants of price change. As discussed in the construction of variables, in this section, the price change is proxied through the importance of demand and cost shocks factors in case of the price increase/decrease, it does not explain the behaviour of price rigidity or flexibility, it indicates the significance of demand and cost factors that might cause to raise or lower the price of main 
products, whenever price change is required. It only explains the determinant of price change. For the demand shocks the variables taken are inflation, change in the price of the competitors, seasonal factors, changes in the tax rate, changes in the demand of your product, change in the level of competition and change in the exchange rate. For the cost shocks the variables taken are inflation, change in labour cost, change in financial cost, change in the cost of raw materials, change in the cost of energy, seasonal factors, government regulations and change in the exchange rate. The firms were asked to indicate the significance of the above factors that might cause to raise/lower the price of firm's product. Average of factors of the cost shocks and demand shocks are taken and are converted into categorical form, by rounding the values to nearest number in given ranking, i.e. 1 to 4 . In this way two series of price change are constructed, which are proxied through the significance of demand and cost factors to change price. Each proxy of price change is regressed on a set of explanatory variables. For simplicity table only provide coefficients or marginal effects, probability and standard errors of variables. The diagnostic tests for all models are given in appendix.

In this section, price change is proxied through the importance of demand and cost shocks variables in price change. Table 2 shows how price change responds to a firm's characteristics and other variables. The significance to demand shocks in price change is measured through four categories, i.e. unimportant $=1$, less important $=2$, important $=3$ and very important $=4$. Then for analysis, these categories are merged into two, i.e. less-important $=0$ and important $=1$, because of unexpected singularities in the Hessian matrix are encountered. Which indicates that either some predictor variables should be excluded, or some categories should be merged? The reference category is less-important $=0$ in table 2 .

According to results in table 2, if firms having imperfect competitive nature (i.e. competition, oligopoly and monopoly) instead of perfect competitive then the odd of demand and cost shocks being important for price change are more than the odd of demand and cost shocks being unimportant, because the odd values is greater than one and coefficients are positive at $1 \%$ significance level in case of oligopoly and monopoly. It implies that if a firm set price according to mark-up pricing policy or jointly set the price with other competitive firms then there is more chance that firm will change price because of demand and cost shocks. It means for imperfect competitive firms (i.e. oligopoly and monopoly), the price change due to demand and cost shocks is important because they have the monopoly power and can increase the price according to internal policies of the firm. While perfect competitive firms depend on the market conditions and are price taker. It means whenever firm change price, it is found that market structure is the important determinants of price change in case of demand and cost shocks. The result is in line with Nakamura et al., (2011); and Kaplan and Menzio, (2015). According to previous literature, as the market share decrease, the chance of firm to increase price will increase due to demand shocks, if firms want to change price. The number of rival firms is the important determinant of price-setting, the monopoly power to set price will increase, if the number of competing firms are less.

According to results in table 2, if a firm has regular customers instead of occasional customers then odd of demand and cost shocks being important for price change are less than the odd of demand and cost shocks being unimportant in case of price increase, because the odd value is less than 1 at $1 \%$ and $10 \%$ significance level. It implies that if firm have regular customers, then there is a less chance that demand and cost shocks become important for price change. In other words, if the proportion of regular customer is greater than occasional customers than the probability of price change because of demand and cost shocks will decrease. It is because to make the regular customers more loyal with the firms and to maintain the market share, the chances of firms to increase price due to shocks in the economy is high in case of the occasional customer then regular customers (Baye and Morgan, 2009). According to Morgan et al. (2006) demand and cost shocks are important determinants of price change in case of occasional customers. According to the Esteves (2010), if the percentage of regular customers is more than the occasional customers, then the response of firms to price change because of demand and cost shocks will be low. It may because of the implicit and explicit contract with the regular customers, while in case the firm of occasional customers, the bond between customers and firms is not strong. 
According to the table 2, if firm pricing decisions are based on current information instead of past information then odd of demand and cost shocks being important for price change is less than the odd of demand and cost shocks being unimportant respectively, because the odd values are less than one and the sign of coefficients are negative at 5\% significance level, while the probability of forecast about the future is insignificant. It implies that firm using current information instead of past information then there is less chance that demand and cost shock in case of price increase becomes important. It means for backward-looking firms, demand and cost shocks are the important determinant of price change, because the firm gives more weight to past information and experience, so the tendency of the firm to choose sub-optimal price will be high because of incomplete information, that whys the firm will change the price because of unexpected economic shock (Steinsson, 2003). While in case of forward-looking behaviour, demand and cost shocks are not important determinants of price change for the firms, because firms used all available information and will anticipate expected shocks, while setting the price of its main product, that whys the price of the firms will be not vulnerable to economic shocks, e.g. demand and cost shocks (Andrade and Le Bihan, 2013). It means backward-looking behaviour (i.e. past information) and forward-looking behaviour (i.e. forecast about future) has important implication for price-setting. According to Reis, (2009), the set of information about price decision minimize the behaviour of the firm to change the price because of shocks.

According to results in table 2, if the firm increase the price according to the situation instead of one shot, then the odd of demand shocks being important for price change is higher than the odd of demand shocks being unimportant in case of price increase, because the value of odd is greater than one and sign of coefficients are positive at $1 \%$ significance level, however the probability of price adjustment in case of cost shocks is insignificant. It implies that if the firm adjusts price (i.e. price increase) according to the situation, then the chance of demand shocks become important will increase. It is in line with the previous literature (Muller and Ray, 2007).

According to the table 2 if firms consider central bank credible instead of non-credible, then the odd of demands and cost shocks being important for price change is higher than the odd of demand and cost shocks being unimportant, because the odd values are greater than 1 and the sign of the coefficients are positive at $5 \%$ significance level. It means firm who accept the credibility of the central bank; then there is more chance that demand, and cost shocks become important. It means credibility of central bank is important determinant of price change in case of demand shocks, while in case of cost shocks it does not play any role in price change. Because according to Blinder, (2000) demand shocks are related to central banks and monetary policy is also demand side policy, that why firms who consider central credible, for them demands shocks are important determinants of price change, while cost shocks are mostly not irrelevant to central banks, that why probability is insignificant.

According to results in table 2, if the firm is economic literate instead of no economic literacy, then the odds of demand and cost shocks being important for price change is more than the odd of demand and cost shocks being unimportant, because the odd values are greater than one and sign of coefficients are positive at 5\% significance level. Which implies if a firm has more information about economic literacy, then demand and cost shocks in case of price increase are important determinants of price change. It means as the economic literacy increases, the firm capability to anticipate the economic shocks will increase. Economic literacy can be important determinants of price change; depends on how much firm trust in the economic policy and institution (Steinsson, 2003).

According to results in table 5.2, as the size of firms' increases, then the odds of cost shocks being important for price change is less than the odd of cost shocks being unimportant, because the odd values are less than one and sign of coefficients are positive at $5 \%$ significance level. The price change in case of demand shocks is independent of the size of firms because the odd values are almost equal to 1 and insignificant. It means as the size of firms increases (decreases) does not affect the price change due to demand shocks. According to previous studies, for large firms, demand and cost shocks are the 
important determinants of price change, because they can easily adjust it, may because of their market share, while for small firms these demand and cost shocks are not significant factors of price change, may because of competition (Jonker, Folkertsma and Blijenberg, 2004).

According to table 2, information set regarding expected inflation is not important determinants of price change in case of demand and cost shocks in case of price increase because the probability is insignificant. Price change due to demand and cost shocks does not depend on information set, because information set, which at best can lead to accuracy of predication. But accuracy does not mean increase in expected inflation; it can be other way round. Better forecast also means lows expected inflation, if inflation is going down. It is in line with the previous literature. Lach and Tsiddon (1992) show that the set of information about expected inflation is positively associated with price flexibility but can be the significant factor of price change.

Table: 3 Determinants of Price change

\begin{tabular}{|c|c|c|c|c|c|c|c|c|c|}
\hline \multirow[b]{2}{*}{ Variables } & \multirow[b]{2}{*}{ Categories } & \multicolumn{4}{|c|}{$\begin{array}{l}\text { Demand Shock } \\
\text { (Price Increase) }\end{array}$} & \multicolumn{4}{|c|}{$\begin{array}{l}\text { Cost Shocks } \\
\text { (Price Increase) }\end{array}$} \\
\hline & & B & S.E. & Sig. & $\operatorname{Exp}(B)$ & B & S.E. & Sig. & $\operatorname{Exp}(B)$ \\
\hline Constant & & -.85 & 1.1 & .44 & .42 & 3.6 & 1.19 & .00 & 38.23 \\
\hline \multirow[t]{4}{*}{ Market Structure } & Competition & & & .00 & & & & .00 & \\
\hline & Monopolistic Competition & -.003 & .54 & .99 & .99 & .48 & .52 & .36 & 1.61 \\
\hline & Oligopoly & 1.03 & .41 & .01 & 2.82 & 1.15 & .38 & .00 & 3.16 \\
\hline & Monopoly & 1.78 & .38 & .00 & 5.96 & 1.01 & .34 & .00 & 2.75 \\
\hline \multirow[t]{3}{*}{ Customer Type } & Occasional Customer & & & .00 & & & & .00 & \\
\hline & Both & -1.38 & .54 & .01 & .25 & -2.5 & .78 & .00 & .08 \\
\hline & Regular Customer & -.29 & .53 & .58 & .74 & -1.3 & .79 & .09 & .26 \\
\hline Backward-looking and & Past Information & & & .08 & & & & .03 & \\
\hline \multirow{2}{*}{ Forward-looking Behavior } & Current Information & -.96 & .48 & .04 & .38 & -.95 & .49 & .05 & .38 \\
\hline & Forecast about future & -.39 & .46 & .38 & .67 & -.24 & .49 & .61 & .77 \\
\hline Price Adjustment & In one shot & & & .00 & & & & .44 & \\
\hline \multirow{2}{*}{ Process } & Gradually & .70 & .44 & .10 & 2.01 & -.52 & .42 & .22 & .59 \\
\hline & Depend on situation & 1.61 & .38 & .00 & 5.04 & -.20 & .34 & .54 & .81 \\
\hline \multirow[t]{2}{*}{ Credibility } & No & & & & & & & & \\
\hline & Yes & 1.71 & .36 & .00 & 5.54 & .64 & .32 & .04 & 1.91 \\
\hline \multirow[t]{2}{*}{ Economic Literacy } & No & & & & & & & & \\
\hline & Yes & .30 & .03 & .04 & 1.35 & 2.01 & .92 & .02 & 7.46 \\
\hline Firm size & & .06 & .28 & .81 & 1.06 & -.77 & .27 & .00 & .46 \\
\hline Information Set* & & .57 & .93 & .54 & 1.77 & .02 & .87 & .97 & 1.02 \\
\hline
\end{tabular}

\section{Conclusion and Policy Implications}

The behaviour of price setting might be affected by several factors related to firm characteristics, market share, type of customers, size of firms, market power, backward and forward information, price adjustment process, expected inflation, economic literacy, credibility of central bank and other factors. In this regard first, these variables are linked with price-setting behaviour through descriptive analysis i.e. how the firms respond to different shocks and characteristics of the firms? What are the determinants and causes of price? Second, to better understand the price-setting behaviour, these variables are modeled using the analytical technique, i.e. logistic regression. According to results firms increase the price is more likely than to decrease price in response to both demand and supply shocks; it means the frequency of price increase is higher than that of price decrease. Furthermore, the response to supply 
shocks that cause to change in the price of product (i.e. both upward and downward) is high than that of the demand shocks. It means supply-side factors lead to higher frequency of price change than demandside factors do. The cost of raw material and cost of energy are the most important causes of price change, both for the price increase and decrease. For imperfectly competitive firms, backward-looking firms, managers having more information about economic conditions, demand and cost shocks are important determinants of price change. If firms have regular customers, then there is a less chance that demand and cost shocks become important for price change. Credibility of central bank is important determinant of price change in case of demand shocks, while in case of cost shocks it does not play any role in price change. Size of firms and information set regarding expected inflation are not important determinants of price change in case of demand and cost shocks in case of price increase. Findings of this dissertation have some policy implications. Credibility of central bank has been found important determinant of price change. Therefore, to stabilize prices and to achieve low inflation, central bank must focus on establishing its credibility. This can be done through effective communication and achieving the targets. Credibility will make output-inflation trade-off favorable for central bank and will help making effective and efficient monetary policy.

\section{Reference}

Andrade, P., \& Le Bihan, H. (2013). Inattentive professional forecasters. Journal of Monetary Economics, 60(8), 967-982.

Ball, L., \& Mankiw, N. G. (1994). Asymmetric price adjustment and economic fluctuations. The Economic Journal, 104(423), 247-261.

Baye, M. R., \& Morgan, J. (2009). Brand and price advertising in online markets. Management Science, 55(7), 1139-1151.

Blaudow, c. And f. Burg (2018): "Dynamic Pricing as a Challenge for Consumer Price Statistics," EURONA, 1, 16.

Blinder, A. S. (1991). Why are prices sticky? Preliminary results from an interview study (No. w3646). National Bureau of Economic Research.

Blinder, A. S. (2000). Near-rational wage and price setting and the long-run Phillips curve. Brookings papers on economic activity, 2000(1), 1-60.

Blinder, A., Canetti, E. R., Lebow, D. E., \& Rudd, J. B. (1998). Asking about prices: a new approach to understanding price stickiness. Russell Sage Foundation.

Choudhary, M. A., Naeem, S., Faheem, A., Haneef, N., \& Pasha, F. (2011). Formal sector price discoveries: Results from a developing country. University of Surrey Discussion Papers in Economics.

Choudhary, M. A., Faheem, A., Hanif, M. N., Naeem, S., \& Pasha, F. (2016). Price setting \& price stickiness: A developing economy perspective. Journal of Macroeconomics, 48, 44-61

Esteves, R. B. (2010). Pricing with customer recognition. International Journal of Industrial Organization, 28(6), 669-681.

Hall, S and Yates, A (1998), 'Are there downward nominal rigidities in product markets?', Bank of England working paper, No 80.

Jonker, N., Folkertsma, C., \& Blijenberg, H. (2004). An Empirical Analysis of Price Setting Behavior in the Netherlands in the Period 1998-2003 Using Micro Data.

Kaplan, G., \& Menzio, G. (2015). The morphology of price dispersion. International Economic Review, 56(4), 1165-1206.

Lach, S., \& Tsiddon, D. (1992). The behavior of prices and inflation: An empirical analysis of disaggregat price data. Journal of political economy, 100(2), 349-389.

Malik, W. S., Satti, A. U. H., \& Saghir, G. (2008). Price setting behaviour of Pakistani firms: Evidence from four industrial cities of Punjab. The Pakistan Development Review, 247-266.

Morgan, John, Henrik Orzen, and Martin Sefton (2006). "An Experimental Study of Price Dispersion." Games and Economic Behavior, 54(1), 134-158.

Muller, G., \& Ray, S. (2007). Asymmetric price adjustment: evidence from weekly product- level scanner price data. Managerial and Decision Economics, 28(7), 723-736. 
Nakamura, E., \& Steinsson, J. (2008). Five facts about prices: A reevaluation of menu cost models. The Quarterly Journal of Economics, 123(4), 1415-1464.

Reis, R. (2009). A sticky-information general-equilibrium model for policy analysis (No. w14732). National Bureau of Economic Research.

Sohail, F., \& Fatima, A. (2018). Price setting behaviour in Pakistan: stylized facts from micro SPI data seta. Pakistan Journal of Applied Economics, 28(2), 253-286.

Steinsson, J. (2003). Optimal monetary policy in an economy with inflation persistence. Journal of Monetary Economics, 50(7), 1425-1456.

Taylor, Jhon. (1999). Staggered Price and Wage Setting in Macroeconomics.In Jhon B. Taylor and michel Woodford (eds.) Handbook of macroeconomics. Ch.15. Elsevier, New York.

Van Reenen, J. (1996). The creation and capture of rents: wages and innovation in a panel of UK companies. The Quarterly Journal of Economics, 111(1), 195-226. 